\title{
Development of the Hudson Bay Region and the North-West Territories of Canada.
}

\author{
By Dr. Brysson Cunningham.
}

THE romance of the mythical 'North-West 1 Passage' which inspired the hopes and fascinated the imaginations of the pioneer navigators of the sixteenth century and their successors for several generations thereafter, has had a curious and interesting sequel of recent years, culminating, after some hesitations and two changes of programme, in the approaching completion of a new commercial port and harbour on the western coast of Hudson Bay, forming the terminal of a branch railway line from the WinnipegPrince Albert section of the Canadian National Railways, and the contemplated inauguration of a regular service of steamers through Hudson Strait to the North Atlantic Ocean. No longer is the extravagant and visionary idea entertained of a new sea route from Europe to India ; in its place has arisen a much more rational and feasible project for the effective development of the spacious and, at present, sparsely occupied regions lying in Manitoba, Saskatchewan, and the great NorthWest Territories of the Dominion, and the systematic exploitation of their enormous wealth of natural resources, by providing them with a direct outlet to the ocean highways of the world.

The vast inland sea, with an area of well over half a million square miles, called Hudson Bay after the famous navigator, penetrates far and deep into the North American Continent (see Fig. 1), and were it not that the sole avenue of communication with the outer Atlantic lies through a region so far north (within $5^{\circ}$ of the Arctic Circle, in fact) as to be blockaded for the greater part of the year by a formidable and impassable barrier of ice, it would be a network of busy trade routes, since its waters lap a coast-line fully as extensive as the entire Atlantic seaboard of the United States. Unfortunately, too, Hudson Bay, which is fairly deep in itself, except along some parts of its south- western shore, is lacking in serviceable natural harbours. On the western and southern coasts (excluding James Bay, which is quite shallow) there are only two inlets which afford any pretensions to shelter and anchorage for vessels of modern draught. These are Nelson and Churchill, situated at the mouths of rivers bearing the same names.

The harbour of Nelson, however, is scarcely more

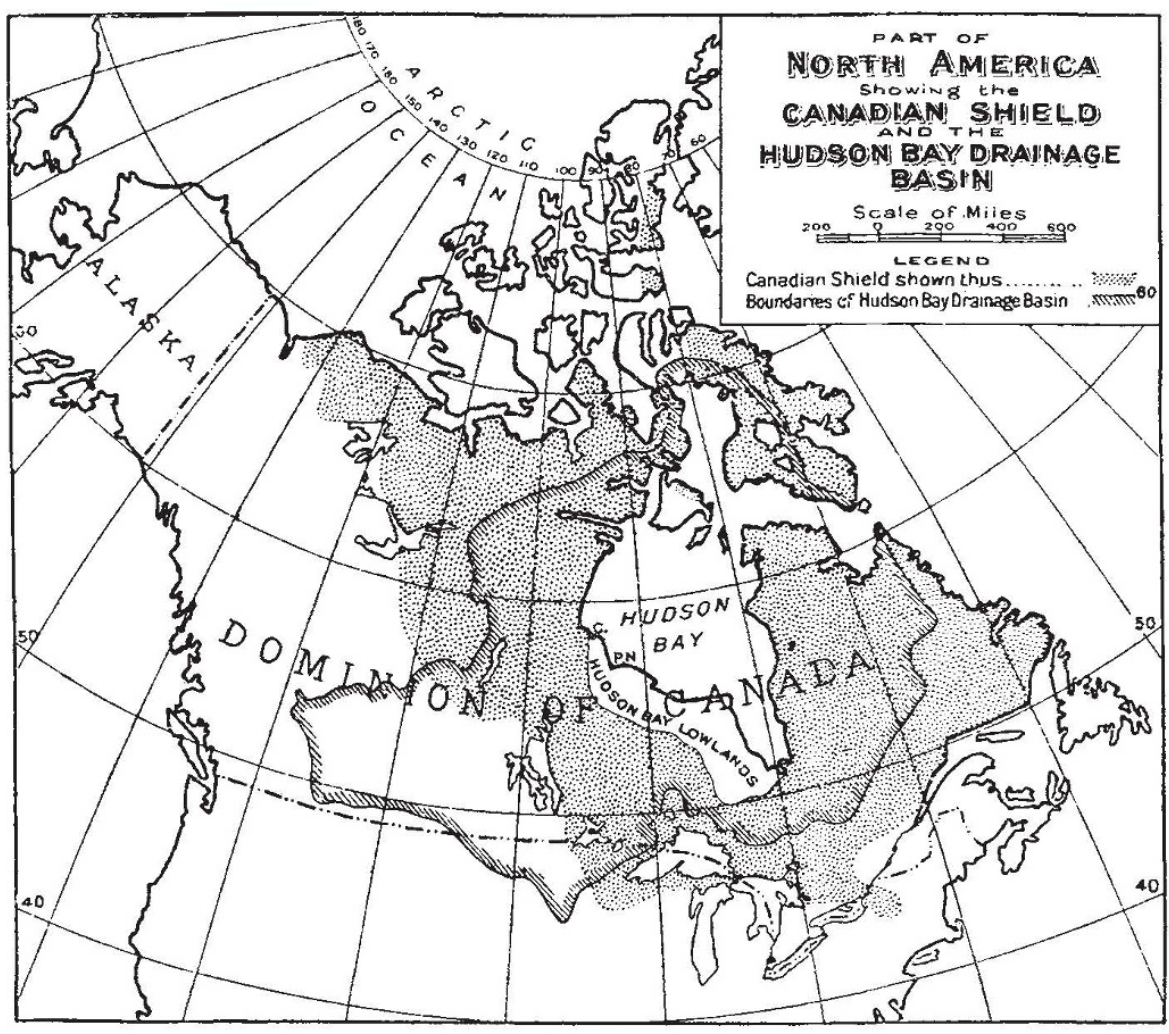

IG. 1.-Churchill and Port Nelson, on the shores of Hudson Bay, are indicated by C. and P.N. respectively. From "The Hudson Bay Region" , by F. H. Kitto, issued by the Department of the Interior and the Natural Resources Intelligence Service, Ottawa.

No. 3219, VoL. 128]

than an open roadstead; it is exposed, shallow, and difficult of approach. Despite the fact that a terminal at Churchill would involve a longer railway line and the consequent drawback of a correspondingly longer haul for traffic, the authorities decided at the outset in its favour, and work was commenced in 1911 on the new branch line, with Churchill as its objective, on a route entirely north of the Nelson River, which measured 474 miles in length from the junction at The Pas with the existing line. For some reason, however, the im. pression gained ground that the constructional difficulties of a line to Churchill would be considerable and even prohibitive, and before much progress had been made, this consideration, combined with the economical question of haulage, caused the Government to alter its plans and to locate the 
railway with the view of an approach to Nelson. This change enabled the route to be shortened by 50 miles, and the line was actually laid for a distance of 332 miles as far as Kettle Rapids (Fig. 2), where the river Nelson is crossed for the second time, the first occasion being at Manitou Rapids. At this stage of progress, the War intervened and operations were suspended.

It was not until 1926 that work was actively resumed, and then the whole question of the rival merits of Nelson and Churchill as prospective port terminals came up for reconsideration. A special Committee of the Senate recommended that expert advice from a leading authority on harbour de- harbour protection works. For, as regards protected harbourage, Churchill presents features indubitably more farourable than those of Nelson. The former port has an easy approach from deep water to a sheltered situation, with ample draught for the requirements of modern shipping. "At Churchill", states Mr. Palmer's report," "Nature has provided magnificent breakwaters, consisting of rocky cliffs rising to heights of from 40 to 70 feet, enclosing a harbour 6 miles in length and from 1 to $2 \frac{1}{2}$ miles in width at low water and $1 \frac{1}{2}$ to 4 miles at high water. The entrance to the harbour consists of a narrow gap between these headlands, with a. low water width of $1600 \mathrm{ft}$., a width of $850 \mathrm{ft}$. at

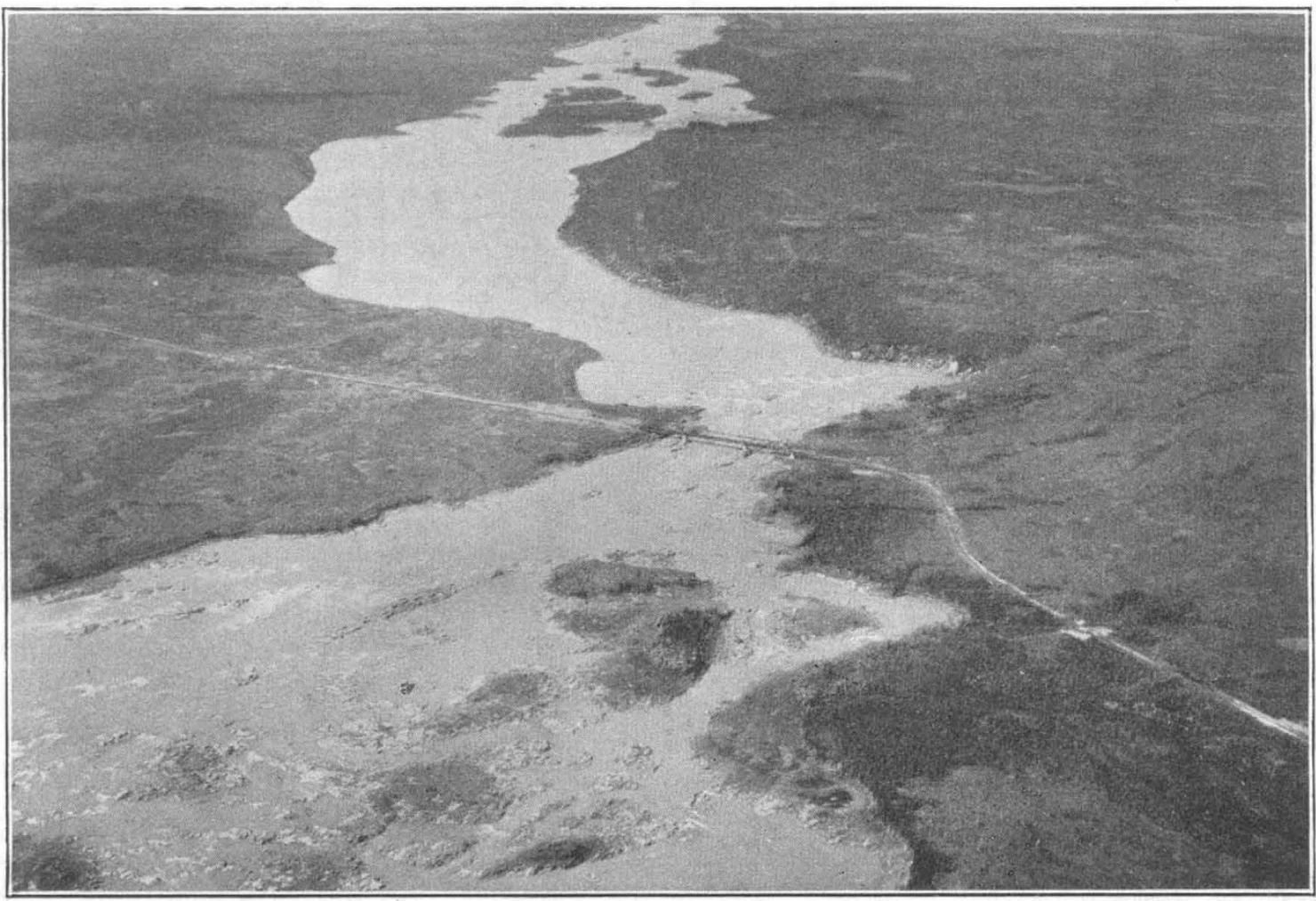

FIG. 2,- View of Kettle Rapids, Nelson River, showing the railway line and crossing. By courtesy of the High Commissioner of Canada.

velopment should be obtained, with the result that Mr. F. Palmer (now Sir Frederick Palmer) was commissioned by the Government to investigate the position and report. Mr. Palmer's conclusions were formulated in the autumn of 1927 . He had no difficulty in deciding that, on all the evidence, the balance of advantages as a port terminal is definitely and unmistakably on the side of Churchill. Moreover, the constructional difficulties of the land route were found to have been greatly over-stated, and it was ascertained that it would be no more difficult to construct a line of railway to Churchill than to Nelson, the only drawback being that the distance is 87 miles greater.

The cost of the longer line, however, could be more than compensated by the saving in artificial
$30 \mathrm{ft}$. depth, and $750 \mathrm{ft}$. of width having depths exceeding $60 \mathrm{ft}$. Inside the entrance there exists an area of 140 acres with depths of $30 \mathrm{ft}$. and over at low water, and a further area of about 180 acres with depths varying from 18 to $30 \mathrm{ft}$. at low water, beyond which there is a vast area of lesser depth."

The Government promptly acquiesced in the findings of this Report, and since that date it has been energetically pursuing the realisation of the project, which, as stated earlier, is now within reach. The site of the wharves and terminal is shown in Fig. 3. The port is expected to be fully open for traffic in 1932, and it is hoped that an experimental shipment of grain will be made during the summer season of this year.

The great problem (and the one uncertain factor 
in the case) is the question of ice. The sole seaward approach to the new port will be through Hudson Strait and the navigability of this passage is only practicable during a season of very restricted extent. As soon as the decision was finally made to adopt Churchill as the strategic point of sea contact, steps were taken to study the environment and navigable channels of the Strait, and an aerial expedition was sent out by the Department of Marine and Fisheries, which established itself for observational purposes on three bases at points on Hudson Strait. The reconnaissance extended from the spring of 1927 to the autumn of 1928 , covering two navigational seasons. stricted, and the prospect of any appreciable extension by modern ice-breaking operations is not altogether too promising, but, on the other hand, it must be remembered that much can be done by intensive seasonal working. Montreal is a port similarly handicapped in regard to ice conditions, though perhaps not quite to the same extent, yet in a short summer season of about seven months no less than 200 million bushels of grain have been shipped and dispatched to Europe. Careful organisation and capable working may lead to correspondingly effective results at Churchill.

Should the experience of the new route prove satisfactory and its commercial feasibility be con-

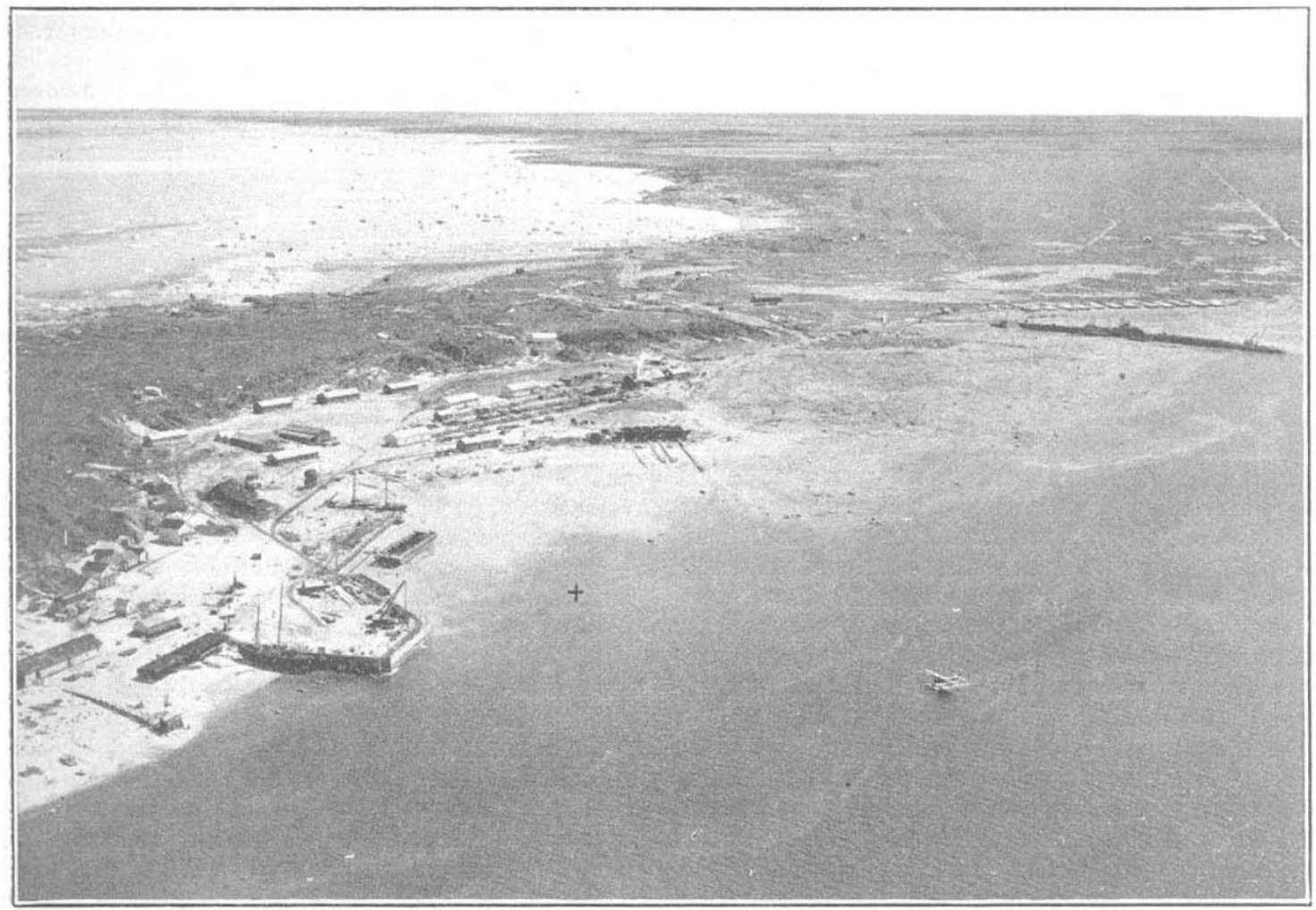

FIG. 3.-Yiew of Churchill Harbour, looking east, and showing the site of the new port terminal. By courtesy of the High Commissioner of Canada.

The report of Capt. N. B. McLean, the officer in charge, cautiously indicates the duration of free navigational movement as about four months in the year. "Taking July 19 as an opening date for the Strait, and November 16, when ice was first reported at Nottingham in 1927, as a closing date, we get a season of 120 days, or practically four months, during which commercial vessels could have navigated with safety and without the assistance of ice-breakers. It must, however, be borne in mind that data obtained during two seasons only is entirely insufficient on which to base any accurate statement in regard to the opening, closing, or length of the season of navigation." 2

The navigational period is obviously very re- firmed, the prospects of developing the almost illimitable hinterland behind the Bay are very alluring. The harvests and agricultural products of the western provinces have hitherto reached the British market either by way of the Great Lakes and the ports of eastern Canada or, alternatively, by the Pacific ports and through the Panama Canal. To Liverpool, the distance from Edmonton or Calgary by the latter route is between 10,000 and 11,000 miles, and by the former about 5200 miles. The Hudson Bay route will mean a further saving of practically a thousand miles.

Apart from the abundant crops of grain and cereals for which Manitoba, Saskatchewan, and Alberta are renowned, there are numerous fields of exploitation in other directions in a region rich

No. 3219 , VoL. 128] 
in natural resources of many kinds. Trapping for furs has long been an established feature, and the Hudson Bay Company, formed so long ago as the year 1670 under the governorship of Prince Rupert, nephew of King Charles I., has carried on a prosperous trade for more than two centuries. The rivers teem with fish. Water power is plentiful and invites conversion at numerous falls into electricity for adaptation to various industries. Forests in the southern areas provide an abundance of timber, with the promise of extensive supplies of pulpwood for paper manufacture, in addition to the considerable number of trees available for constructional and commercial purposes.

Not less remarkable is the scope for mining minerals and precious metals. The great preCambrian area covering very nearly the whole of the Hudson Bay region, and known as the Canadian Shield, has given startling evidence of being one of the world's largest storehouses of mineral wealth. The famous Hollinger mine is third among the largest gold producers in both hemispheres. There are impressive copper-zinc ore deposits in northern Manitoba and massive bodies of ferriferous ore on the Belcher Islands in Hudson Bay.

The country is still largely in the exploratory stage, and much of its wealth yet remains to be discovered. From such evidence as has accumulated to date, it is clear that there is every ground for believing that the internal resources of the Hudson Bay region will prove highly remunerative and profitable to the capable prospector. The opening of the new route to Europe will afford a means of facilitating the initiation of further enterprise, and will doubtless lead to a great era of commercial, industrial, and agricultural development in the inland provinces of western Canada.

2 "Report on the Selection of a Terminal Port for the Hudson Bay Railway", October 1927.

2 "Report of the Hudson Strait Expedition, 1927-8." Ottawa, 1929.

\section{Modern Whaling.}

CO far as historical records show, whaling was D first begun in the twelfth century by the Biscayans in the Bay of Biscay. From that time until the beginning of the present century, all whaling stations were situated on land.

Towards the end of the nineteenth century, Svend Foyn had tried to operate a floating factory, but the venture failed. The next attempt in this direction was made by Commander Christensen when, in 1903, he sent a wooden steamer fitted as a temporary factory and accompanied by two attendant catchers to Svalbard (Spitsbergen). So much success attended this expedition that Christensen afterwards bought the steel steamer Admiralen and fitted her out as the first fully equipped floating factory. This proved to be an epoch-making vessel. In 1925 she was sent to South Georgia, accompanied by two catchers, and from that date the great modern Antarctic whaling era may be said to have begun. There are now one Argentine, three British, and four Norwegian companies operating at South Georgia, and seven Norwegian companies at South Shetland, in addition to various other shore and pelagic factories working elsewhere in the Antarctic.

Prior to the outbreak of the War, some twentyfour steamers had been converted into whaling factories, but all worked in or near harbours, depending - in part at least-upon water and other supplies from the shore. Since the War about the same number of ships have been converted, but the majority of the latter are designed to work in open seas entirely independent of any shore base. The pioneer in this field of development was the renowned whaler, Capt. C. A. Larsen.

Until roughly five years ago, all the working up of whales was done in the water alongside the factory ships, the blanket of blubber and severed pieces of the carcass being hoisted on board by winches and derricks. To avoid the labour and discomfort involved in such a trying and uneconomical method, by means of some kind of slipway which would enable the entire carcass to be hauled on board, had long been the dream of many a whaleman. Numerous suggestions were put forward and a number of ships fitted with various types of slipway. These were located in different parts of the vessels--from bow to quarter -but not one proved satisfactory. Not until the introduction of a straight slipway through the stern was success eventually achieved. The great obstacle in the way of a straight slip was the profound respect with which all sailors regard the stern frame and rudder post of a ship.

In 1925 the "Globus "Company bought the s.s. Flackwell (now Lancing) for conversion into a pelagic whaler. Mr. Chr. Fred Christensen, in cooperation with Capt. H. G. Melsom, supervised the reconstruction of this ship. With commendable courage they decided to make drastic alterations and arranged a straight and permanent slipway down to the waterline through the stern-a process which necessitated the cutting away of about eleven feet of rudder stock and stern frame post.

This revolutionary design proved highly successful, and has formed the model for all subsequent slipways. Improvements quickly followed until what the designers consider full efficiency was attained in the Vikingen - a new ship designed and built specially as a pelagic whaling factory at Messrs. Swan, Hunter and Wigham Richardson's Wallsend shipyard in 1928.

In a very valuable and intensely interesting handbook * just published, Mr. Christensen describes this ship. Plans of the vessel are given, along with detailed information regarding the arrangement of

* The Whaling Factory Ship Vikingen, with some Notes on Whaling. By Chr. Fred Christensen. (Neweastle-on-Tyne: North-East Coast Institution of Engineers and Shipbuilders, 1931.) Pp. $24+2$ plates. n.p.

No. 3219, VoL. 128] 